\section{Genetic counseling of ventricular tachycardias}

To the Editor,

I read with interest the article, "Clinical spectrum and longterm course of sustained ventricular tachycardia in pediatric patients: 10 years of experience" by Şengül et al. (1). However, I did not find any mention of genetic evaluation in these patients, especially in the 14 patients with sudden cardiac deaths in their families at a young age. In addition, $65.9 \%$ of the patients were grouped as having "idiopathic VT." Did they have any genetic testing?

Inherited cardiac arrhythmias [long OT syndrome, short OT syndrome, catecholaminergic polymorphic ventricular tachycardia (CPVT), and Brugada syndrome] give rise to ventricular tachycardias, and these rare diseases are often the underlying cause of sudden cardiac death in young individuals. Mutations in several genes encoding ion channels or proteins involved in their regulation are often the underlying cause and can now be tested. For example, in CPVT, the RYR2 gene mutations have autosomal dominant inheritance, and CASO2 and TECRL have autosomal recessive interitance pattern (2).

As more patients with congenital heart diseases reach adulthood and have children, it is of utmost importance that they have genetic counseling. Genetic counseling can also help in diagnosis and managing the course of disease.

\section{Hande Kaymakçalan Çelebiler (D)}

Pediatric Genetics Unit, Department of Pediatrics, Faculty of Medicine, Demiroğlu Bilim University; İstanbul-Turkey

\section{References}

1. Şengül FS, Kafalı HC, Güzeltaş A, Ergül Y. Clinical spectrum and long-term course of sustained ventricular tachycardia in pediatric patients: 10 years of experience. Anatol J Cardiol 2021; 25: 313-22. [Crossref]

2. Schwartz PJ, Ackerman MJ, Antzelevitch C, Bezzina CR, Borggrefe $\mathrm{M}$, Cuneo BF, et al. Inherited cardiac arrhythmias. Nat Rev Dis Primers 2020; 6: 58. [Crossref]

Address for Correspondence: Dr. Hande Kaymakçalan Çelebiler, Demiroğlu Bilim Üniversitesi Tıp Fakültesi, Çocuk Sağlığı ve Hastalıkları Anabilim Dalı, Çocuk Genetik Bilim Dalı, İstanbul-Türkiye

Phone: +90 2122136486

E-mail: doctorhande@yahoo.com

(C) Copyright 2021 by Turkish Society of Cardiology -

Available online at www.anatoljcardiol.com

DOI:10.5152/AnatolJCardiol.2021.412

\section{Author’s Reply \\ To the Editor,}

We would like to thank the authors for their interest in our manuscript "Clinical spectrum and long-term course of sustained ventricular tachycardia in pediatric patients: 10 years of experience" (1) and for taking the time to express their concerns.

Ventricular tachycardias (VT) are potentially life-threatening arrhythmias that can cause sudden cardiac death. Inherited cardiac arrhythmias and cardiomyopathies are also the underlying cause of sudden cardiac death in young individuals (2-4). As you mentioned in the article titled, "Genetic counseling of ventricular tachycardias" we agree that genetic counseling has a crucial role in the diagnosis and management of inherited arrhythmias/cardiomyopathies. However, the primary objective of our study was to define the clinical aspects of pediatric patients who were diagnosed as having sustained VT. In our study, patients with cardiomyopathies, catecholaminergic polymorphic VT (CPVT), and patients without structural heart disease were included; however, patients with Brugada syndrome and those who developed ventricular fibrillation as long OT syndrome were excluded. Therefore, we did not mention the genetic results of the patients in our article.

We appreciate their acknowledgment of the genetic screening of patients with such life-threatening arrhythmias. The genetic test results of patients diagnosed with cardiomyopathy in our study were as follows: PKP2 ( $n=1)$, RYR2 $(n=1)$, and DSG-2 $(n=1)$ gene mutations and normal genetic screening $(n=2)$ were detected in patients with arrhythmogenic right ventricular dysplasia (ARVD/C) (5). ACTN2 ( $n=1)$ and TTN ( $n=2)$ gene mutations were detected in patients with left ventricular noncompaction cardiomyopathy, and MYH7 ( $n=2)$ and MYBPC3 $(n=2)$ gene mutations were detected in patients with hypertrophic cardiomyopathy (6). In addition, RYR2 ( $n=6)$, CASO $(n=4)$, TRDN ( $n=2)$, and KCNJ2 $(n=1)$ gene mutations were detected in patients diagnosed with CPVT. Actually, if there is no suspicion of any cardiomyopathy (especially $A R V D / C$ ), we do not routinely screen for genetic mutations in patients with idiopathic VT. In this study, we had a confusing case in the idiopathic VT group of an infant who had been previously treated at our clinic with radiofrequency catheter ablation for multidrug-resistant, recurrent VT episodes; and he had had three more sessions of ablations that were performed at another center; however, he deceased suddenly at home shortly thereafter. We could not perform cardiac MRI and genetic screening in this case. As a developing country, as genetic studies could not be performed routinely in our clinic before 2015, the patients who were diagnosed before then do not have genetic results. However, after 2015. genetic studies were performed on patients suspected clinically. 
Ultimately, we agree with the authors that patients with lifethreatening arrhythmias need genetic counseling for accurate diagnosis and management of the disease.

Fatma Sevinç Şengül (D), Yakup Ergül (D)

Department of Pediatric Cardiology, University of Health Sciences, İstanbul Mehmet Akif Ersoy Thoracic and Cardiovascular Surgery Training and Research Hospital; İstanbul-Turkey

\section{References}

1. Şengül FS, Kafalı HC, Güzeltaş A, Ergül Y. Clinical spectrum and long-term course of sustained ventricular tachycardia in pediatric patients: 10 years of experience. Anatol J Cardiol 2021; 25: 313-22. [Crossref]

2. Priori SG, Wilde AA, Horie M, Cho Y, Behr ER, Berul C, et al. HRS/ EHRA/APHRS expert consensus statement on the diagnosis and management of patients with inherited primary arrhythmia syndromes: document endorsed by HRS, EHRA, and APHRS in May 2013 and by ACCF, AHA, PACES, and AEPC in June 2013. Heart Rhythm 2013; 10: 1932-63. [Crossref]

3. Al-Khatib SM, Stevenson WG, Ackerman MJ, Bryant WJ, Callans DJ, Curtis AB, et al. 2017 AHA/ACC/HRS Guideline for Management of Patients With Ventricular Arrhythmias and the Prevention of
Sudden Cardiac Death: A Report of the American College of Cardiology/American Heart Association Task Force on Clinical Practice Guidelines and the Heart Rhythm Society. J Am Coll Cardiol 2018; 72: e91-220.

4. Towbin JA, McKenna WJ, Abrams DJ, Ackerman MJ, Calkins H, Darrieux FCC, et al. 2019 HRS expert consensus statement on evaluation, risk stratification, and management of arrhythmogenic cardiomyopathy. Heart Rhythm 2019; 16: e301-72. [Crossref]

5. Sevinç Şengül F, Tunca Şahin G, Özgür S, Kafalı HC, Akıncı O, Güzeltaş $A$, et al. Clinical features and arrhythmic complications of patients with pediatric-onset arrhythmogenic right ventricular dysplasia. Anatol J Cardiol 2019; 22: 60-7. [Crossref]

6. Tunca Sahin G, Ozgur S, Kafali HC, Sevinc Sengul F, Haydin S, Guzeltas $A$, et al. Clinical characteristics of hypertrophic cardiomyopathy in children: An 8-year single center experience. Pediatr Int 2021; 63: 37-45. [Crossref]

Address for Correspondence: Dr. Yakup Ergül,

Sağlık Bilimleri Üniversitesi, İstanbul Mehmet Akif Ersoy Göğüs Kalp ve Damar Cerrahisi Eğitim ve Araştırma Hastanesi,

Çocuk Kardiyoloji Kliniği; İstanbul-Türkiye

Phone: +90 2126922000

E-mail: yakupergul77@hotmail.com

(C) Copyright 2021 by Turkish Society of Cardiology -

Available online at www.anatoljcardiol.com 